\title{
Nadir bir prostat kanseri: Primer taşlı yüzük hücreli adenokarsinom
}

\section{A rare prostate cancer: Primary signet ring cell adenocarcinoma}

Türk $\mathrm{H}^{1} \quad$ Ün $\mathrm{S}^{2} \quad$ Koca $\mathrm{O}^{3} \quad$ Yoldaş $\mathrm{M}^{1} \quad$ Tarhan $\mathrm{H}^{1}$

${ }^{1}$ Tepecik Eğitim ve Araştırma Hastanesi, Üroloji Kliniği, Izmir, Türkiye

${ }^{2}$ Katip Çelebi Üniversitesi Tıp Fakültesi, Üroloji Kliniği, İzmir, Türkiye

${ }^{3}$ Horasan Devlet Hastanesi, Üroloji Kliniği, Erzurum, Türkiye

\section{Özet}

Prostatın primer taşı yüzük hücreli karsinomu nadir görülen bir histolojik varyanttır. Genellikle mide, kolon, pankreas ve daha nadir olarak mesaneden kaynaklanır. Klasik prostat adenokarsinomlarına göre daha kötü prognoza sahiptir. Primer prostatın taşlı yüzük hücreli adenokarsinom tanısını koymadan önce, bu adenokarsinomu taklit eden bazı durumların dışlanması gerekir. Bu yazıda, kısa sürede yükselen prostat spesifik antijen (PSA) nedeniyle kemoterapi başlanan prostatın taşlı yüzük hücreli adenokarsinomu olgusu sunulmaktadır.

Anahtar Sözcükler: Prostat karsinomu, taşlı yüzük hücreli adenokarsinom.

\section{Summary}

Primary signet ring cell adenocarcinoma of the prostate is a rare histologic variant. It usually originates from stomach, colon, pancreas and rarely from the bladder. Compared with usual adenocarcinomata of prostate, it has a worse prognosis. Before diagnosing signet ring cell adenocarcinoma of the prostate, we need to eliminate some conditions that imitate adenocarcinoma. In this article, a patient with primary signet ring cell adenocarcinoma of the prostate is presented in which chemotherapy was given due to the rapid rising prostate specific antigen (PSA) level.

Key Words: Prostate carcinoma, signet ring cell adenocarcinoma

\section{Giriş}

Prostatın primer taşı yüzük hücreli karsinomu nadir görülen bir histolojik varyanttır. Taşlı yüzük hücreli karsinom, adenokarsinomun müsin salgılayan bir alt tipidir. Salgılanan müsin nedeniyle nükleusun perifere itilmesiyle oluşan yüzük görüntüsünden dolayı bu isimle anılırlar. Müsin salgılamayan tipleri de vardır (1). Genellikle mide, kolon, pankreas ve daha nadir olarak mesaneden kaynaklanır (mide karsinomlarının \%3.4'ü) (2). Prostatta nadir görülürler ve tanı konulduğu anda genellikle ileri evrededirler. İlk defa prostatta 1979 yılında tanımlanmıştır. O günden beri 69 olgu bildirilmiş ve bu bildirilen olgularda ortalama sağkalım 28 ay olarak tesbit edilmiştir $(3,4)$. Bu hastaların yaş ortalaması 68.2 yıldır (1). Klasik prostat adenokarsinomlara göre daha kötü prognoza sahiptirler (5). Bu yazıda, tespit edildiğinde ileri evrede olan, klasik adenokarsinomda uygulanan antihormonal tedaviye çok iyi yanıt vermeyen ve kısa sürede yükselen prostat spesifik antijen (PSA) düzeyi nedeniyle kemoterapi başlanan prostatın taşlı yüzük hücreli adenokarsinomu olgusu sunulmaktadır.

Yazışma Adresi: Hakan TÜRK

Tepecik Eğitim ve Araştırma Hastanesi, Üroloji Kliniği, İzmir, Türkiye

Makalenin Geliş Tarihi: 16.01.2014

Kabul Tarihi: 25.02.2014

\section{Olgu Sunumu}

Zorlanarak idrar yapma şikayetleriyle başvuran 66 yaşındaki erkek hastada, kronik obstrüktif akciğer hastalığı (KOAH) ve diabetes mellitus (DM) mevcuttu. Özgeçmiş ve soygeçmişinde kanser öyküsü yoktu. PSA değeri $>100 \mathrm{ng} / \mathrm{dL}$ olması üzerine prostat biyopsisi yapıldı. Gleason skoru 4+5=9 adenokarsinom, tüm odaklarda pozitif olarak raporlandı. Direkt akciğer grafisi normal, batın tomografisinde bilateral hidronefroz, paraaortik, parailiak multiple lenfadenopatileri mevcuttu, kemik sintigrafisinde multipl kemik metastazları gözlendi. Titrimetrik PSA değeri $6658 \mathrm{ng} / \mathrm{dL}$ olan hastaya leuprolid asetat (LHRH) analoğu başlandı. Torakolumbal veretebralarda multiple metastazları olması ve kompresyon fraktürü riski nedeni ile acil radyoterapi yapıldı. Hastanın akut üriner retansiyonları olması nedeniyle pasaj transüretral rezeksiyon (TUR) yapıldı. Patolojisi taşlı yüzük hücreli komponent içeren az diferansiye adenokarsinom (WHO Grade III, Gleason skoru $5+5=10$ ) olarak raporlandı. Taşlı yüzük hücreli komponenti nedeniyle primer başka odak araştırıldı ancak bulunamadı. PSA düzeyi önce $441 \mathrm{ng} / \mathrm{dL}$ 'ye kadar geriledi, kemik sintigrafisinde metastaza ait bulgular azaldı. Kısa bir süre sonra PSA değeri hızla yükseldi. 
Hastaya $50 \mathrm{mg}$ antiandrojen (bicalutamid) eklendi ancak yanıt alınamadı. Kastrasyon dirençli prostat kanseri kabul edilerek dosetaksel $\left(75 \mathrm{mg} / \mathrm{m}^{2}\right)$ tedavisine başlandı. Dosetaksel tedavisine rağmen PSA yanıtı alınamadı ancak kısmen ağrı şikayetleri azaldı. Kemoterapiden çok iyi yanıt alamadığı için abireteron planlandı ancak hasta genel durum bozukluğu ve sonrasında gelişen ürosepsis nedeniyle tanıdan 22 ay sonra exitus oldu.

\section{Tartışma}

Klinik olarak primer prostatın taşlı yüzük hücreli adenokarsinomu klasik prostatın adenokarsinomlarına benzer olarak obstrüktif ve irritatif şikayetlerle ortaya çıkabildiği gibi metastaza ait semptomlar da verebilir. Olgumuzda obstrüktif şikayetlerle başvurmuş ve tanı konulmuştur. Bu hastaların yaklaşık \%42'si tanı anında T4 evresindedirler. Bu da taşlı yüzük hücreli adenokarsinomun agresifliğini gösterir $(1,2)$.

Taşlı yüzük hücreli tanımı karsinom hücrelerinin stoplazmik geniş vokuollerinin hücre çekirdeklerini perifere itmesi sonucu ortaya çıkan görüntüden dolayıdır (1). Taşı yüzük hücreli adenokarsinom genellikle kolon, pankreas ve memeden kaynaklanır, primeri prostat olan taşlı yüzük hücreli adenokarsinom nadir bir durumdur. Primer prostatın taşlı yüzük hücreli adenokarsinom tanısını koymadan önce bu adenokarsinomu taklit eden bazı durumların dışlanması gerekir. Lenfositlere infiltre prostat lenfoması, radyoterapi ve antihormonal tedavi sonrası düz kas hücrelerinin görünümü taşlı yüzük hücreleri taklit edebilir $(1,2)$. Olgumuzda da LHRH uygulandıktan altı ay sonra yapılan pasaj TUR patalojisi taşlı yüzük hücreli adenokarsinom gelmesi, bizleri de antihormonal tedaviye bağlı bir durum olabileceğini düşündürdü ancak yapılan immünhistokimyasal boyama ile bu durum dışlandı. Leucocyte common antigen (LCA), alpha-smooth muscle actin (ASMA), sitokeratin 7 ve 20'nin negatif ve PSA'nın pozitif olması tanıyı güçlendirir (3-6). Carcinoembryonic antigen (CEA), literatürdeki vakaların \%20'sinde pozitif olarak bulunmuştur (10).

PSA ve prostate specific acid phosphatase (PSAP) vakaların \%87'sinde pozitif bulunmaktadır (10). Yine bildirilen olgularda periodic acid-schiff stain (PAS) \%60, alcain blue $\% 60$, mucicarmin $\% 50$ pozitif olarak bulunulmuştur (11). Bazı yazarlar taşlı yüzük hücrelerinin tümör dokusunda \%20'den fazla bulunması gerektiğini vurgulamışlardır $(10,11)$. Olgumuzda da PSA, PAS, PSAP, alcain blue gibi immünhistokimyasal belirleyiciler kullanılmış ve pozitif bulunmuştur. Ayrıca LCA, ASMA, CEA ve sitokeratin 7 ve 20 de negatif olarak belirlendiğinden olgumuzun patolojisi taşlı yüzük hücreli adenokarsinom olarak rapor edildi.

Primer prostat taşlı yüzük hücreli adenokarsinom tanısındaki güçlüklerden biri de diğer organlardan metastaz intimalini dışlamaktır. Gastrointestinal sistemde bir tümör odağı olup olmadığı radyolojik ve endoskopik olarak dışlanmalıdır (3). Olgumuzda kolerektal ve gastroözafajiyal endoskopi ile gastrointestinal sistem taranmış ve başka bir odak bulunamamıştır.

Prostatın primer taşlı yüzük hücreli adenokarsinomu klasik prostat adenokarsinomuna göre agresif, tedaviye rağmen kötü prognozludur. 3 yıllık sağkalım \%55, 5 yıllık sağkalım \%12 civarındadır. Olgumuzun sağkalımı 22 aydır. Literatürde bildirilen olguların antihormonal tedaviye yanıtı kötüdür $(7,9)$. Olgumuzda da kısa süreli LHRH tedavisine yanıt alınmış ancak sonrasında bu tedaviye direnç gelişmiştir. Bir çalışmada kolerektal kanserlerde kullanılan kemoterapi ile (oxaliplatin, 5-FU, leucovorin) tama yakın cevap alındığı bildirilmiştir (8). Yapılan çalışmalarda prognozun tanı anındaki evresi ile yakın ilişkili olduğu gösterilmiştir (8).

Primer prostatik taşı yüzük hücreli adenokarsinomu nadir görülen bir histopatolojik varyanttır. Primer olduğunu göstermek için gastrointestinal sistem taranmalı ve başka odak olmadığı gösterilmelidir. Diğer taşlı yüzük hücreli karsinomların aksine prostatik taşlı yüzük hücreli adenokarsinom, klasik adenokarsinom gibi tedavi edilir. Nadir görülen bir durum olması, agresif bir tümör olması ve tanı anında genellikle ileri evre olması nedeniyle prognozu kötüdür. Verilen tedavilere rağmen yeterli yanıt alınamaması bu konu ile ilgili araştırma ve yeni tedavi modaliteleri intiyacını doğurmaktadır. Bu hastalar kombine tedavilerle agresif olarak tedavi edilmeli ve yakın izleme alınmalıdır.

\section{Kaynaklar}

1. Fujita K, Sugao H, Gotoh T, Yokomizo S, Itoh Y. Primary signet ring cell carcinoma of the prostate: Report and review of 42 cases. Int J Urol 2004;11(3):178-81.

2. Kwon W, Oh TH, Ahn SH, Lee JW, Park SC. Primary signet ring cell carcinoma of the prostate. Can Urol Assoc J 2013;7(1112):768-71.

3. Skodras G, Wang J, Kragel PJ. Primary prostatic signet-ring cell carcinoma. Urology 1993;42(3):338-42.

4. Smith C, Feddersen RM, Dressler L, McConnell T, Milroy T, Smith AY. Signet ring cell adenocarcinoma of prostate. Urology 1994;43(3):397-400.

5. Kuroda N, Yamasaki I, Nakayama H, et al. Prosatatic signet-ring cell carcinoma: Case report and literature review. Pathol Int 1999;49(5):457-61.

6. Guerin D, Hasan N, Keen CE. Signet ring cell differentiation in adenocarcinoma of the prostate: Study of five cases. Histopathology 1993;22(4):367-71. 
7. Akagashi K, Tanda $\mathrm{H}$, Kato S, et al. Signet-ring cell carcinoma of the prostate effectively treated with maximal androgen blockade. Int J Urol 2003;10(8):456-8.

8. Roldán AM, Núñez NF, Grande E, García AÁ, Antón-Aparicio LM. Primary signet ring cell carcinoma of the prostate with bone metastasis with Impressive response to folfox and cetuximab. Clin Gen Cancer 2012;10(3):199-201.

9. Lilleby W, Axcrona K, Alfsen GC, Urnes T, Hole KH. Diagnosis and treatment of primary signet-ring cell carcinoma of the prostate. Acta Oncol 2007;46(8):1195-7.

10. Randolph TL, Amin MB, Ro JY, Ayala AG. Histologic variants of adenocarcinoma and other carcinomas of prostate: Pathologic criteria and clinical significance. Mod Pathol 1997;10(6):612-29.

11. Torbenson M, Dhir R, Nangia A, Becich MJ, Kapadia SB. Prostatic carcinoma with signet ring cells: A clinicopathologic and immunohistochemical analysis of 12 cases, with review of the literature. Mod Pathol 1998;11(6):552-9. 